\title{
COMMODITY AGREEMENTS AND AID TO DEVELOPING COUNTRIES
}

\author{
RaYMond F. MIKESEIL*
}

INTRODUCTION

Recently there has been a renewed interest in international commodity agreements as a mechanism for assisting less developed countries. This has come about in considerable measure as a consequence of the change in United States government policy toward commodity agreements, as evidenced by the willingness of the Administration to participate in the International Coffee Agreement which was signed in 1962 , and ratified by the United States Senate on July I, 1963 , and to consider sympathetically various proposals for other individual commodity agreements and compensation schemes for decreases in export proceeds. It is the purpose of this paper to analyze the relationship between commodity arrangements of various types and direct economic aid for the promotion of economic development in the low income regions of the world. But before dealing with specific types of commodity arrangements, we shall discuss briefly the relationship between trade problems and external assistance for developing countries..

There has been a tendency on the part of both economists and public officials to treat international trade policies and foreign economic assistance as two separate though related areas of concern. Some years ago "trade not aid" became a popular slogan in the United States in both private and governmental circles, but it was gradually suppressed by economists who pointed out that aid and trade were not substitutes for one another, especially in the case of countries that lacked the resources for expanding their productive capacities sufficiently to meet both their export and some consumption requirements. It is quite likely, however, that the economic development economists have gone too far in emphasizing external assistance as against trade policies in their prescriptions for economic growth. External assistance without opportunities for export cannot achieve viable economies. There are many spokesmen for the less developed countries, especially Latin Americans, who regard efforts to increase the prices and expand markets for their coffee, cocoa, bananas, and mineral exports as having a far higher priority than external capital and technical assistance.

While "aid plus trade" constitutes a better slogan than "trade not aid," both miss the point that trade opportunities and economic assistance are highly interdependent and inseparable conditions for economic growth. This is true for several reasons. First, fluctuations in export earnings as a consequence of short term movements in world prices and demand may impair investment because of a shortage of foreign exchange for capital goods imports. Second, export demand is an important stimulus

- B.A., M.A. 1935, Ph.D. 1939, Ohio State University. W. E. Miner Professor of Economics and Associate Director of the Institute of International Studies and Overseas Administration, University of Oregon. 
to both domestic and foreign private investment in developing countries. Moreover, as countries reach the stage at which they begin to produce capital equipment and durable consumer goods, domestic demand is usually insufficient to support capacity production in plants of an economical scale. Hence, export markets are indispensable for reaching higher stages of industrialization. 'Third, economic development requires a steady growth in export proceeds in order to provide exchange for growing import requirements of capital goods and raw materials, and for debt service and other goods and services for which domestic substitutes are either not available or could be made available only at extremely high cost. Fourth, it follows from the points made above that economic planning and investment priorities established both by the developing country and by external assistance agencies must take into account the export potentials of the developing country in relation to world trade policies affecting the commodities concerned. In the case of primary commodities such as coffee, these policies may relate to the negotiation of international commodity agreements, the maintenance of revenue tariffs imposed by the major importing countries, and the negotiation of discriminatory tariff arrangements such as those in effect between the European Economic Community (EEC) countries and certain African countries. Of growing importance also are restrictions on imports of both competing primary products and manufactures imposed by the industrialized countries of North America and Western Europe.

There has been a failure on the part of national and international agencies concerned with economic development to view aid and trade as integral parts of the same problem. This is not to say that public and private officials have not been aware of the relationship of both aid and trade policies to development. For example, the General Agreement on Tariffs and Trade (GATT) Secretariat has been quite active in conducting studies on the relationship between economic growth and export earning requirements of low income countries, and various GATT committees have been concerned with the problem of increasing the opportunities of the less developed countries to export both primary and manufactured commodities to the industrially advanced areas. The Organization for Economic Cooperation and Development (OECD) is charged with the problem of coordinating both aid and trade policies of its members, especially with respect to the less developed countries, and some progress has been made in the field of aid coordination by the Development Assistance Committee (DAC) of the OECD. However, little progress has been made with respect to the coordination of aid and trade policies and programs as they affect individual developing countries.

\section{Categories of Commodity Problems}

In the following paragraphs we shall identify several categories of problems relating to the exports or export earnings of low income countries and show the relationship between these problems and commodity agreements, on the one hand, 
and foreign aid (which we will define provisionally as the transfer of resources by national or multi-national public agencies for promoting economic development), on the other.

\section{A. Ironing Out Price Fluctuations}

A true stabilization operation has as its objective the reduction of the amplitude of the movement of prices over a period of years, which may be caused by a variety of factors affecting both world demand and supply. Where the purpose of a commodity agreement is to iron out the peaks and the troughs of price movements, no attempt is made to interfere with long-term trends which are determined by longrun supply conditons (which may be affected by changes in costs in producer countries, the development of new producing areas, and so on) or by long-term demand conditions (which may be affected by world income elasticities of demand, competition from synthetics, trade policies, and so on). Under commodity price stabilization programs, an effort is made to maintain prices at long-term equilibrium levels but to allow them to move upwards or downwards as long-term demand and supply conditions dictate changes in the long-term equilibrium price. The elimination of sharp fluctuations in prices will mitigate changes in export proceeds, which have disequilibrating effects on the domestic economies of the producer countries. Sharp fluctuations in export prices may produce an uneconomical pattern of investment by inducing heavy investment in periods of high prices, followed by low returns and uneconomical use of capacity in subsequent periods of low prices and demand. By improving the distribution of investment resources, stabilization operations help to make external aid more effective and may often reduce the need for external assistance to deal with crises arising out of sharp reductions in export prices. Thus, the provision of a certain amount of capital from external sources to finance the stabilization schemes which by their very nature do not, or should not, involve net transfers of capital to producer countries over a long period of time, can constitute a highly effective use of foreign aid funds.

\section{B. Supporting Commodity Prices at Desired Levels}

Schemes for supporting international commodity prices at desired levels, even though they are often spoken of as stabilization programs, depend basically on limiting supply in relation to world demand in order to realize the desired price objectives. Since full cooperation of all countries producing for the world market may be difficult to obtain, agreements for limiting exports may be supplemented by commitments on the part of major importing countries to maintain import quotas as a means of helping the agreement countries to enforce their export quotas and of limiting imports from non-agreement countries. Cooperation by the industrialized countries in the maintenance of import prices of commodities exported mainly by the less developed countries at levels higher than otherwise would have 
prevailed, constitutes in effect a tax on their consumers for the benefit of the producer countries. Since the non-industrialized areas export over $\$ 20$ billion's worth of primary goods per year to the industrialized countries, a twenty-five per cent increase in the prices of these exports would amount to over $\$ 5$ billion, which is nearly equal to the total amount of annual official aid to the less developed countries.

However, only certain primary commodities lend themselves to artificial price support, since a number of primary commodity exports of less developed countries are competitive with, or close substitutes for, commodities produced by the industrialized countries themselves, e.g., cotton and rubber. Even in the case of commodities like coffee, there are limits upon the level to which prices should properly be raised, even from the standpoint of the long-run interest of the producing countries themselves. Not only is there some elasticity of demand, as was indicated by the consumers' reaction to the sharp rise in coffeee prices during the mid-I95o's, but high prices would stimulate efforts to develop and market synthetic coffee. Perhaps more significantly, however, we may raise the question as to whether the industrialized countries could promote economic development abroad more effectively by paying higher than equilibrium prices for their imports, or by making the same amount of funds available in the form of foreign aid. This depends in part upon the policies followed by the producer countries as regards both the means employed in reducing exports in accordance with the quotas, and the employment of the additional export proceeds resulting from higher prices.

\section{Compensation for Shortfalls in Export Proceeds}

The difficulties in negotiating individual commodity agreements, plus the fact that commodity agreements are feasible for only a few primary commodities exported mainly by the less developed countries, led to the formulation and serious consideration of schemes for compensating low income countries for reductions in their total export proceeds. Schemes for compensating shortfalls in export proceeds do not interfere with market forces determining the prices of individual commodities. Basically they constitute a form of loan or grant assistance which is tied to the behavior of export proceeds and, to the extent that the funds for compensation come from the low income countries themselves, they constitute a form of mutual assistance. The relationship of compensatory schemes to economic development is obvious. The basic purpose is to prevent short-run reduction in export proceeds from impeding economic growth either as a consequence of the effect of sharply reduced domestic incomes on investment, or of reduced exchange availabilities for the acquisition of capital goods imports required for investment.

\section{Long-Term Trends in Terms-of-Trade or Export Proceeds}

A fourth category of commodity problems is represented by alleged or projected long-run downward trends in the prices of primary commodities in relation to the 
prices of manufactured goods, or of declining or stagnating export proceeds from traditional exports of low income countries over long periods of time. While there is no general agreement among economists regarding the long-run outlook for relative prices of primary commodities as a group, there are several factors which indicate that at least over the next couple of decades, the prices of agricultural exports are more likely to decline than to rise relative to the prices of manufactures. More significant, however, is the likelihood that for most low income countries, the growth of export proceeds from traditional primary commodity exports will not be sufficient to meet the foreign exchange requirements consistent with their development goals. Therefore, they must diversify their exports and increase their exports of manufactures if their export proceeds are to grow in a satisfactory manner. Neither the long-run terms of trade problem (if one exists) nor the problem of slowly growing or stagnating exports can be dealt with satisfactorily by commodity agreements.

It is generally recognized by economists and officials in developed and underdeveloped countries alike that these problems can only be solved by a change in the economic structure of the low income countries. However, world trade policies, as they affect imports of both primary goods and manufactured products of the developed countries, have an important bearing on this category of problems. Moreover, commodity agreements which assure less developed countries a certain share of the world market for products such as sugar, wheat, and textiles, which compete with those produced in the industrially advanced countries, may provide a means of mitigating the effects of import restrictions imposed by the industrial countries of Western Europe and North America.

\section{II}

\section{The Magnitude of Commodity Problems}

The quantitative significance of the instability of world commodity markets for the low income countries has been measured in various ways and with respect to particular categories of problems. Average annual variations in export prices and export values have been calculated both for individual commodities and for primary commodities as a group. Thus, during the 1948 - $195^{8}$ period, the average year-to-year change in export values ranged from four per cent for crude petroleum to thirty per cent for rubber, while the weighted average of year-to-year fluctuations for the export values of all primary commodities was about twelve per cent. However, measures of year-to-year fluctuations in export values have little real significance unless they are adjusted for longer-run trends, and the calculated magnitudes of the fluctuations will differ substantially, depending upon the methods employed in constructing trend lines.

From the standpoint of the impact on the economies of the producer countries, the most meaningful category of trade instability is the instability of the total export 
proceeds of the individual countries. But here again, significant measures of export proceeds instability should be corrected for trends. For example, a country whose exports rose ten per cent each year for the past decade would show a significant degree of instability on the basis of average year-to-year changes, unless allowance is made for the long-run growth trend. But the problem of choosing a suitable method of correcting for trends presents both statistical and conceptual difficulties. For instance, the average annual fluctuations in export proceeds of primary exporting countries during the 1948 -1958 period is twelve per cent when calculated by means of a trend line fitted by the least squares method, ${ }^{1}$ and eight per cent when calculated by means of a five-year moving average. ${ }^{2}$

In a recent statistical study of the instability of export proceeds during the postWorld War II period, Professor Joseph D. Coppock employs a "log variance" method for calculating an instability index of export proceeds, which shows the average year-to-year relative changes corrected for trend influence. ${ }^{3}$ Using this method, which avoids some of the biases to be found in other measures, Coppock finds that for the period 1948-1959 "export proceeds were decidedly more stable for primary goods than for manufactured goods." $\mathrm{He}$ also found that for some eighty countries, instability of export proceeds of the individual countries was not positively correlated with Gross National Product (GNP) per capita and, in addition, instability of export proceeds was not highly correlated with instability of imports. ${ }^{4}$ Coppock also shows that, contrary to popular opinion, there is little or no correlation between export instability and growth in real GNP among the countries studied for the period 195 I-r 957 .

Since many commodity schemes are designed for the stabilization of prices as the principal method for achieving stabilization of export proceeds of individual countries or producer groups, Coppock examined the relationship between instability of export receipts and instability of prices. While he found some degree of positive correlation in the sense that export proceeds tend to become more unstable as export prices are more unstable, Coppock concludes that "the evidence here falls far short of demonstrating a strong connection between instability of export prices and instability of export proceeds." Thus, in his policy conclusions Coppock states that since "export quantum instability is clearly much more important than export price instability in determining proceeds instability," it is generally better to stabilize export proceeds directly than to stabilize prices. However, these findings have not led Dr. Coppock to the position that instability of export proceeds does not constitute a serious problem for many countries. In fact, he offers

${ }^{2}$ U.N. Dep't of Econ. \& Soc. Affirs, World Economic Survey, 1958, at 40 (I959) (U.N. Pub. Sales No. 59.II.C.I).

'Fund Policies and Procedures in Relation to the Compensatory Financing of Commodity Fluctuations, 8 Int' l Monetary Fund Staff Papers I (I960).

${ }^{3}$ See Joseph D. Coppock, International Economic Stability 23-25 (1962).

Id. at $35, \mathrm{ro8}, \mathrm{I} 42$.

Id. at III. 
a proposal for an International Short-Term Credit Corporation (ISTCC) which might operate as an affiliate of the International Monetary Fund (IMF). The function of the ISTCC would be to make loans to countries experiencing reductions in their export proceeds by more than a certain percentage of the "normal value" of their exports-normal value being calculated from the long-term trend. ${ }^{\circ}$

\section{A. Terms of Trade}

Commodity problems of low income countries are frequently analyzed with respect to movements of the terms of trade, either for the low income countries as a group or by means of comparisons between prices of primary commodities and prices of manufactured goods. Meaningful measures of changes in terms of trade are fraught with difficulties; and a variety of conclusions may be obtained, depending upon what year is chosen as the base. For example, it would scarcely be proper to use 195I, a year of exceptionally high prices of primary commodities generated by the Korean War, as a basis for comparing changes in the terms of trade. Yet any year we may choose may be regarded as abnormal for some commodities and for some countries. If we use I953, the first post-Korean War year, as the base, we find that for the non-industrial countries as a group, terms of trade declined by about five per cent between 1953 and 196x (as a consequence of a decline in the average export unit value index offset in part by a decline in the import unit value index). ${ }^{7}$ However, for the Latin American countries, the weighted terms of trade index fell by fifteen per cent between 1953 and $196 x$, mainly, as a consequence of a seventeen per cent decline in the export unit value index. For Brazil, the unit value export index declined about. forty-five per cent, mainly as a result of the fall in coffee prices. ${ }^{8}$ In the case of the Asiatic countries (excluding Japan), there was a slight improvement in terms of trade between 1953 and $196 \mathrm{r}$, since the decline in the prices of foodstuffs and certain agricultural materials was offset by higher prices for jute, rubber, and tin. On the other hand, prices of these three commodities had fallen precipitously in 1953 from their Korean War highs.

The longer the period under consideration, the less meaningful are changes in terms of trade, since they do not take into account the changes in the quality of manufactured imports (which would compensate, at least in part, for the rise in prices of manufactured exports since 1953), and for changes in the character of the import market basket. As Professor Kindleberger has pointed out, an index of the terms of trade based on the relationship between an index of world prices of primary goods and an index of prices of manufactures not only presents complex statistical problems, but its conceptual significance over long periods of time is highly questionable. ${ }^{9}$ For these and other reasons, we must conclude that changes in the terms

${ }^{\circ} \mathrm{Id}$. at $\mathrm{I} 49 \mathrm{f}$.

${ }^{7}$ U.N. Monthly Bulletin of Statistics, July I962, pp. $x$-xi.

${ }^{8}$ International Financial Statistics, Jan. 1963, pp. 36-37.

' Kindleberger, The Terms of Trade and Economic Development, 40 REv. Econ. \& Stat. 80 (Spec. Supp. 1958). 
of trade, while perhaps significant for some purposes, do not provide us with a significant measure of the nature and magnitude of the commodity problems faced by the low income countries. Nor are economists agreed with respect to the longrun outlook for the terms of trade between primary commodities and manufactures. On the other hand, it is possible to project demand and supply relationships for certain commodities over, say, the next five years, and to forecast the possible consequences of these relationships for prices and export proceeds.

\section{B. Quantitative Relationships Between Foreign Aid and Reductions in Export Proceeds as a Consequence of Lower Terms of Trade}

It has been suggested that in recent years the less developed countries have lost, through declining terms of trade, as much as-if not more than-the amount of foreign aid that they are receiving from industrialized countries. The implication is that if terms of trade could be restored to some level that the less developed countries regard as normal or fair, this would mean as much or more to them than the foreign aid which they are receiving.

This assertion may or may not be true, depending upon which years are selected for comparison and the countries or regions involved. In rg6r, estimated official net aid from all DAC countries to the low income countries totalled approximately $\$ 6$ billion, ${ }^{10}$ while total exports from less developed countries in Ig6r amounted to $\$ 27.5$ billion. If the value of $196 \mathrm{I}$ exports of the low income countries were adjusted for the eighteen per cent decrease in terms of trade between $195 \mathrm{r}$ and Ig6r, the increment would be approximately $\$ 6$ billion. This figure would, of course, need to be further adjusted for the fact that a portion of the exports of the low income countries went to other low income countries so that the net calculated gain would be somewhat less than $\$ 6$ billion. However, in I95I, prices of primary commodities were at their peak as a consequence of the sharp rise in demand occasioned by the Korean War. A comparison between 1952, or 1953, and I96I indicates only a six per cent decrease in terms of trade, or a loss of export value in Ig6r prices of $\$ \mathrm{I} .7$ billion, as against $\$ 6$ billion in net foreign aid.

It might be more reasonable to compare Ig6r terms of trade with the average terms of trade for the low income countries for the period $1954-\mathrm{x} 956$ following the post-Korean slump in primary commodity prices. When this is done, the loss in export value amounts to about $\$ 2.8$ billion, or less than half the net official aid in 196r. As has already been pointed out, terms of trade for various countries or groups of countries have behaved quite differently over the postwar period. For the Latin American countries, terms of trade reached a peak in 1954 , but declined nearly thirty per cent by $\mathrm{x} 96 \mathrm{r}$, and for some Latin American countries, such as Brazil, the decline has been even greater. Hence, by choosing the base period from which to measure

${ }^{10}$ Hearings Before the loint Economic Committee on Outlook for U.S. Balance of Payments, 87th Cong., $2 d$ Sess. $7 x$ (xg62). 
changes in terms of trade, at least some countries can arrive at the conclusion that if they had maintained their export prices at peak levels, they would have gained more than the aggregate amount of aid received during a certain period. But such statistical exercises are not especially useful for determining policy. Nor is there any guarantee that foreign exchange acquired in the form of higher export prices would stimulate growth just as effectively as a carefully administered aid program of a smaller magnitude. In fact, just the opposite is likely to be true.

\section{Long-Run Outlook for Export Proceeds from Traditional Primary Commodities}

Of greater significance as a measure of the commodity problems which confront the low income areas is the current and prospective increase in the value of their exports in relation to their foreign exchange requirements for exports and debt service. Over the eight-year period $1953-\mathrm{rg} 6 \mathrm{r}$, the low income countries of the Free World increased the value of their exports by only twenty-seven per cent, or at a compound rate of about three per cent per annum, and the vast bulk of this increase occurred between 1953 and 1957. On the other hand, imports of these same countries rose by nearly fifty per cent during this period, or a compound rate of over five per cent per annum. A considerable portion of this difference in the rates of growth of imports and exports can be accounted for by the eight per cent decrease in the unit value index of exports between 1953 and xg6r. Even so, however, the rate of growth of imports, financed in part by external aid and by a drawing down of foreign exchange reserves, was insufficient to meet the requirements of many countries for a two per cent per annum growth in output per capita. Moreover, statistics on average annual increases in exports for low income countries conceal the fact that while exports of a number of petroleum and mineral exporting countries, such as Venezuela, Kuwait, and the Rhodesian Federation, have been soaring over the past decade, exports of such important countries as Argentina, Brazil, Egypt, India, Indonesia, and Pakistan have been stagnating or even declining. ${ }^{11}$

An even more significant indication of the commodity problems of less developed countries is to be found in the projections of world demand for the primary commodity exports of the low income countries in relation to their foreign exchange needs. The GATT secretariat has sought to provide some indications of the gap between minimal import requirements for manufactures and the value of exports of traditional primary products in 1975, assuming that the less developed countries grow at the "minimal desirable rate" of five per cent per annum. Under the somewhat optimistic assumption that primary product prices in 1975 will equal the $1956-60$ average (which means a relative price increase of thirteen per cent above the $196 \mathrm{r}$ level), this gap for Southeast Asia alone is calculated at $\$ 7$ to $\$ 8$ billion by 1975 . (1962).

${ }^{21}$ See Raymond F. Mikeseli (Ed.), U.S. Private and Government InVestment Adroad 402-03 
Gross imports of manufactured products of Latin American countries have been projected at $\$ 10.5$ billion for 1975 , but the Latin American countries hope to meet the bulk of these requirements by regional substitution and the expansion of intraLatin American trade in manufactures. If this does not take place, there will be a large gap to be met by exports of manufactures to the developed countries. ${ }^{12}$

While all projections of this kind are fraught with difficulties, it seems clear that almost regardless of the policies followed by the industrialized countries with respect to imports of traditional primary commodities from the low income countries, there will be a growing gap between exports of traditional primary products and import requirements for manufactured goods, and that unless sufficient foreign aid were available for filling this gap, which might increase by as much as $\$ 1_{5}$ billion from the current level, low income countries will have to expand enormously their exports of manufactures, both to one another and to the industrialized countries. Nor can the problem be solved by import substitution, since many of the more industrially advanced of the less developed countries have already largely exploited the scope for import substitution of consumer and intermediate producer goods. ${ }^{13}$ Moreover, since their domestic markets are not large enough to support plants of an economical size to produce the large variety of capital goods required for growth, the less developed countries must specialize in the production of a limited number of manufactures and exports to one another and to the world at large, if they are to achieve higher stages of industrialization. In other words, they must follow the pattern of the industrialized countries of Europe who have found that trade in industrial products is indispensable to growth and prosperity.

\section{III}

\section{Individual Commodity AgreEments}

We shall now consider briefly several types of individual commodity agreements from the standpoint of their contribution to the economic development of the countries concerned. There are three basic types of individual commodity agreements: (I) international buffer stock arrangements designed to maintain prices within a given range by means of purchases and sales from the buffer stock; (2) multilateral long-term contracts involving an agreement among exporting and importing countries to sell or purchase minimum amounts within a certain price range; and (3) export quota agreements (which may be supplemented by import quotas imposed by importing members of the agreement) designed to maintain prices at or near the desired level by means of limiting market supply. There are certain technical advantages and disadvantages to each of these basic types of arrangements, or combinations of them, but it is beyond the terms of reference of this paper to

\footnotetext{
${ }^{12}$ Sec Contracting Parties to the General agreement on Tariffs and Trade (GATT), InternaTtonal Trade, rg6r, at 8-22 (1962).

${ }^{18}$ See U.N. Dep'T of Econ. \& Soc. AFFarrs, World Economic SuRVEY, Ig6I, at 60 (1962) (U.N. Pub. Sales No.: 62.II.C.I).
} 
discuss them in detail. Although the history of international commodity agreements does not provide much encouragement as to their effectiveness for increasing or maintaining export prices over long periods of time, or of avoiding the creation of conditions which make for even greater instability once the agreements break down, this is no reason for rejecting them out of hand or of abandoning experiments with new types of agreements. By and large the agreements which have been negotiated in the past have been producers' agreements or, where governments of consumer countries have been involved, they either lacked sufficient resources (as in the case of the International Tin Agreement based on the buffer stock principle) or not all of the major producers and consumers have been members.

\section{A. Buffer Stock Arrangements}

Which type of commodity agreement is most appropriate depends in considerable measure upon the objectives to be served and the nature of the commodity in question. For example, where the basic purpose is to eliminate sharp and reversible fluctuations in world market prices of storable commodities, the buffer stock technique offers important advantages. Under this arrangement, no export quotas or other trade controls need be employed and no attempt is made to interfere with price movements indicated by long-term trends. The buffer stock manager should be permitted to operate freely on the basis of his informed judgment regarding long-run demand and supply conditions, and he should be provided with sufficient resources in the form of both foreign exchange and commodities to offset reversible fluctuations peculiar to the demand and supply pattern of the individual commodity. From the standpoint of the importing countries who may contribute all or a large share of the funds for financing the buffer stock, the arrangement has significant advantages, since its operation does not necessarily involve a higher average level of prices, and the elimination of sharp price fluctuations, which serve no economic purpose so far as the allocation of resources is concerned, tends to promote greater stability in the world economy as a whole. Moreover, a buffer stock arrangement need not involve, over a period of years, large net tranfers of economic assistance.

On the other hand, a buffer stock arrangement may not be appropriate for commodities, such as cocoa, which are not storable except for relatively short periods, or where the purpose to be served is not "stabilization" in the sense of ironing out reversible fluctuations about a trend, but rather the supporting of prices at other than long-term equilibrium levels by means of direct controls over supply. For example, a buffer stock arrangement would perhaps be of little help in the case of coffee, where the industry is faced with a severe problem of long-run disequilibrium. It has been estimated that in the absence of measures for controlling output, production over the next five or six years will be twenty-five to thirty per cent in excess of world demand. ${ }^{14}$ Since the demand for coffee is quite inelastic, prices and export (1962). 
receipts would be reduced drastically to perhaps half their current level. Eventually, of course, the very low prices would lead to the abandonment of many coffee plantations and to cessation of new plantings for a number of years, following which there would occur a very sharp rise in prices with world demand and supply again out of balance. As a consequence, there would be heavy investment in the industry and a new long-term cycle would be initiated.

Theoretically, a sufficiently large buffer stock operation operating over a ten or twelve year cycle (because of the long gestation period of coffee trees) might be employed to iron out these fluctuations, but several factors mitigate against this approach. First, the funds available to the manager would need to be quite large, perhaps several billion dollars and, in addition, the long period of the cycle would make it difficult to anticipate a long-term trend and to distinguish between the trend and the cyclical movements. What seems to be called for is a structural adjustment in the industry, particularly for those countries like Brazil that are so heavily dependent upon coffee for their foreign exchange earnings. Thus, under the International Coffee Agreement of I962, world prices are to be supported by a combination of export and import quotas, while provision is made for production controls to be imposed by individual members, which are consistent with the export quotas established. However, production controls cannot be undertaken without consideration for the reallocation of human and material resources currently devoted to coffee production. Certainly the imposition of marketing and production controls with respect to various crops in the United States has not solved our basic agriculture problem.

\section{B. Export Quota Agreements}

There are severe limitations on what can be done for promoting the economic welfare and development of less developed countries through individual commodity agreements. Only a few commodities lend themselves well to agreements of any kind, and there are technical and political difficulties in reaching agreements which cover the bulk of the world's production and consumption. In considering the desirability and feasibility of such agreements the following conclusions and principles are suggested:

(I) The ideal type of commodity arrangement, and one which involves the least cost and the greatest benefits to the importing countries, is that designed simply to iron out fluctuations above and below long-term equilibrium price trends. However, such an approach is appropriate or feasible for only a very few primary commodities.

(2) Assistance by developed countries in financing and helping to police export quota agreements, or by entering into long-term contracts to purchase commodities at prices above equilibrium levels, constitutes a form of economic aid. Therefore, the costs and benefits of such agreements must be carefully weighed against other forms of assistance. 
(3) Where commodity agreements provide for the establishment of prices above longer-term equilibrium levels through the imposition of export and import controls, they should be accompanied by structural adjustments in the major producing countries. Ideally, the producer country should work toward a modernization of its primary product industry, which will result in higher productivity and lower costs (or higher returns to the factors), and this should occur even though output is prevented from rising at a faster rate than world demand.

For many less developed countries, increased investment for modernization and higher productivity in the primary product industries will not be encouraged either by low or by high prices in the absence of special governmental action or incentives. Moreover, if under an international export quota system domestic output is maintained and above-quota surpluses purchased and accumulated by the government, there is an unproductive investment in stocks, and resources will not be employed for making the structural adjustments necessary for increased productivity and full utilization of the resources of the economy. Under these conditions, assistance to less developed countries for maintaining prices of their exports at disequilibrium levels will scarcely constitute an effective use of the resources represented by the higher prices paid by the importing countries. Therefore, structural adjustments in line with increased productivity should constitute an important part of the development plans of the producing countries as a condition for cooperation on the part of importing countries joining with producing countries in international commodity agreements. The implementation of such plans should also be related to other forms of economic assistance to the producer country.

\section{Multilateral Agreements of Maintaining or Expanding Export Markets}

A special type of international commodity agreement might be employed with respect to primary commodities imported by industralized countries, which are competitive with domestic products. Such agreements could take the form of either a multilateral contract such as the International Wheat Agreement, or an agreement which provides for minimum import quotas to be established by net importing countries. Certain temperate zone commodities such as cereals, sugar, cotton, and wool, as well as a number of metals and fuels, are of importance to both high income countries, e.g., United States, Canada, and Australia, and to low income countries, e.g., Argentina, Mexico, Peru, Egypt, and Uruguay, alike. (In fact, industrial areas imported a larger volume of primary products from other industrial areas in Ig6I (\$24.6 billion) than they did from non-industrial areas (\$20.8 billion). $)^{15}$ Thus, international commodity agreements for commodities such as sugar and wheat have been suggested as a means of preserving a portion of the markets of external producers of these commodities in the European Economic

\footnotetext{
${ }^{15}$ See GATT, International Trade, 196r, at 24 (1962).
}

TrADE, Ig6I, at 24 (Ig62). 
Community. ${ }^{16}$ Admittedly, such agreements will be difficult to negotiate since they should be on a world-wide basis in order to avoid bilateralism and discrimination. Nevertheless, they may constitute the only means of preventing regional trading groups, such as the EEC, from becoming virtually self-sufficient in a number of commodities as a result of high internal prices maintained by tariffs and quantitative import restrictions. Moreover, since the EEC permits free entry of a number of tropical products such as coffee and cocoa from the Associated African countries, world-wide agreements may provide a means of reducing the degree of discrimination against similar products coming from Latin America and Asia.

\section{IV}

\section{Multilateral Agreements for Stabilizing Export Proceeds of the Low Income Countries}

The realization that individual commodity agreements are at best suitable for only a handful of commodities important to the less developed countries has led to the formulation of proposals for stabilizing or mitigating sharp reductions in total export proceeds. ${ }^{17}$ We shall not be concerned here with the details of the various proposals that have been put forth, but rather with the principles involved as they apply to low income countries. Schemes for compensating countries for reductions in export proceeds shift the focus of concern from commodities to the balance of payments, or one element of the balance of payments. The balance of payments approach directs attention to the fundamental problem arising out of trade instability for the low income countries, and not simply to a contributing factor. Price instability for many products is not closely correlated with instability of export values, and even a high degree of price stability for the major primary products might still leave a number of low income countries with a substantial degree of instability of export proceeds. Moreover, it is doubtful whether much reliance can be put upon calculated trend lines for total export proceeds in determining whether a given reduction in export proceeds is reversible.

By and large, proposals for dealing with instability of export proceeds have been of two types: (I) those which provide for grants or contingent loans to cover reductions in export proceeds in accordance with some formula; and (2) those which provide for loans which must be repaid within a reasonable period of time regardless of the future behavior of export proceeds. ${ }^{18}$ Type (I) proposals involve grants or

${ }^{10}$ For an excellent discussion of this problem, see Caine, Commodity Agreements-A New Look, Lloyd's Bank Review, Jan. 1963 , p. 14 .

${ }^{17}$ For a discussion of these proposals, see Mikesell, International Commodity Stabilization Schemes and the Export Problems of Developing Countries, 53 AM. Econ. Rev. PAPers and Procegdings 75 (I963).

${ }^{18}$ An example of type (I) is represented by the United Nations Experts' proposals (see UNITED NatroNs International Compensation for filuctuations in Commodity Trade, Report by a Commattee of EXPERTS Appointed BY THE SECRETARY-General (I96I); type (2) is represented by the proposal of an OAS group (sec Organization of American States, Final Report of the Group of Experts on Stabilization of Export Proceeds (Doc. No. 59, rev. 5) (I962). 
loans of a definite maturity to countries experiencing reductions in export proceeds in accordance with an automatic formula, while type (2) is, except for its automatic nature, more akin to the operations of the International Monetary Fund (IMF). The usual formula for compensation is based on reductions in export proceeds from the average of the three preceding years. While both types of proposals involve a form of external assistance, we may recognize a significant difference in principle between automatic grants or contingent loans, on the one hand, and short or intermediate term financing of a self-liquidating nature, in the form of obligations with a maximum maturity, on the other.

Type (2) compensation arrangements raise several significant questions. First, since the purpose is to deal with the balance of payments problem arising out of fluctuations in export proceeds, is it desirable to establish an automatic compensation mechanism which looks at only one aspect of a country's balance of payments? Any formula for calculating automatic compensation for shortfalls in export proceeds is likely to be arbitrary and unrelated to the balance of payments problem of a particular country. For example, a sharp fall in export proceeds from the previous year may constitute a serious balance of payments problem for a particular country, but if compensation is provided on the basis of the average export proceeds of the three preceding years, it is conceivable that the decline from the moving average may be relatively small, while the decline from the preceding year is significant. ${ }^{10}$ Moreover, an examination of the countries experiencing deficits over the period 1959-196r, shows that in the majority of cases their export proceeds rose rather than declined in each of these years. Their deficits were mainly a consequence of increased imports, or their balance of payments difficulties arose from having to meet a large volume of maturing debt incurred in earlier years. Thus, if we are basically concerned with the balance of payments problem, it is questionable whether an automatic scheme based on a highly arbitrary formula relating to only one aspect of the balance of payments is the appropriate solution.

There seems little reason why the functions envisaged in type (2) proposals could not be appropriately performed by the IMF, which considers the need for short or intermediate term assistance from the standpoint of the balance of payments of the country as a whole. If the resources of the Fund are inadequate for meeting temporary and reversible deficits of low income countries arising mainly from instability of export proceeds, they should be augmented for this purpose or, if

\footnotetext{
10 Assuming the operation of a compensation scheme for shortfalls in exports from a threc-year moving average, let us suppose that for a given country in year One, export proceeds are 100, in year Two, 115, and in year Three, I30, giving us an average for the three years of 215 . But in the fourth year, this country's exports fall from 130 back to 110 . Assuming a minimum reduction from the three-year moving average of $5 \%$ before any compensation was paid, this particular country would realize no compensation for a $17 \%$ decline in export proceeds from the preceding year. On the other hand, if the country's export proceeds had remained reasonably stable over the previous three-year period before, the $17 \%$ decrease in export proceeds would have entitled the country to the compensation equivalent to $12 \%$ of its total exports.
} 
the quotas of these countries are too small, they should be increased, or above-quota drawings should be authorized by the IMF. There is certainly no evidence at present that the Fund's resources are insufficient to deal with this problem. In fact, during Ig6I drawings by low income countries from the Fund totalled approximately $\$ 900$ million, while at the same time export proceeds of these countries were rising over the levels of the previous year. ${ }^{20}$

The principal argument for type (I) proposals and, hence, the major objection to leaving the job to the Fund, is that countries experiencing shortfalls in their export proceeds in accordance with an automatic formula may be unable to repay the amount of the compensation within a reasonable period of time or, in fact, may be unable to repay at all if the long-term trend of receipts is downward. It is true, of course, that the IMF is not designed to make long-term loans or grants, but it may also be objected that long-term loans or grants are not appropriate for dealing with balance of payments deficits in accordance with some automatic formula. This raises the basic question how aid should be provided and what conditions should be attached to the administering of an aid program. Simply providing automatic and unconditional financing for balance of payments deficits gives no assurance that proper steps will be taken to remove the causes of the deficits or that the capital funds transferred will be employed in investment activities designed to promote economic growth and external equilibrium. Clearly, long-term loans or grants may be both desirable and necessary to enable a country to make the structural adjustments for dealing with declining export proceeds or with other causes of external disequilibrium. But such capital assistance should not be made on an automatic basis and without regard to how the capital funds are used in relation to the recipient's long-range development plan.

\section{V}

\section{A Proposal for Dealing with the Export Problems of Less Developed Countries}

In the preceding paragraphs, we have identified several types of export problems of developing countries and the solutions appropriate to them. For a limited number of cases, individual commodity agreements may prove useful; at least there is merit in experimenting with them, provided certain principles are followed. But for most less developed countries, the basic export commodity problem consists of instability of export proceeds, and-perhaps more importantly-of achieving a rate of growth in foreign exchange earnings consistent with their long-run development goals. As regards instability of export proceeds in the sense of fluctuations likely to be reversed within a period of two or three years, this is basically a balance of payments problem

\footnotetext{
${ }^{20}$ Since this article was written, the IMF liberalized its facilities for balance of payments assistance to member countries experiencing deficits arising from temporary declines in their export earnings. See International Monetary Fund, Press Release No. 43 I, March 5, 1963.
} 
and should be dealt with in the context of the balance of payments as a whole. Assistance, where required, is the province of the IMF; and a convincing case has not been made that this problem cannot be handled by the Fund within the limits of its present resources and the charter under which it operates.

But the larger and more serious problem of stagnating or declining export proceeds cannot be dealt with either by the IMF or by any formula for automatic compensatory financing. The solution of this problem requires a concerted approach which must include both the trade policies and the foreign aid programs of the industrialized countries and of international assistance agencies. This approach also requires close cooperation with the officials of the low income countries responsible for their development policies and programs. While it is beyond the terms of reference of this article to deal with the entire field of foreign aid in relation to the promotion of economic growth in low income countries, the following suggestions are made with special reference to commodity exports.

I. There should be established, possibly under the auspices of the OECD or its Development Assistance Committee (DAC), a committee on commodity problems of low income countries. This committee might consist of representatives from the IMF, the International Bank for Reconstruction and Development (IBRD) (which would also represent its subsidiary, the International Development Association), the GATT Secretariat, the Inter-American Development Bank, and a representative of the United Nations Economic and Social Council. While the committee or its secretariat might prepare studies and issue general recommendations from time to time on the commodity trade problems of less developed countries, it would have the more specific function of analyzing and making recommendations with respect to the problems of individual countries or groups of producer countries experiencing balance of payments difficulties arising out of declining or stagnating export proceeds. In the first instance, the countries experiencing balance of payments difficulties from this source would approach the IMF but, as already noted, the IMF is only equipped to handle balance of payments deficits which are of a relatively short-term and reversible nature. Even where the IMF is in a position to provide some assistance, longer-term structural problems may exist which call for other types of assistance. Such assistance might take the form of grants or long-term loans designed to improve the export capacity of the country, or action in the trade policy field may be required.

2. Upon request by either a low income country or an external assistance agency, the committee would study, perhaps with the aid of a special mission to the country, the export problems of the individual country, and make recommendations for its solution, both to the government of the country in question and to the external assistance agencies. It would also serve as a coordinator of activities with respect to the implementation of the recommendations among the agencies concerned.

3. Recommendations for the long-run solution of export problems would need 
to take into account regional and world market potentialities for the products of the countries in question. Out of these considerations would come specific recommendations for changes in trade policies or for trade negotiations for broadening export markets, which would be transmitted by both the GATT and the OECD to its members, including regional groups such as the EEC and the Latin American Free Trade Area Association.

4. Recommendations regarding trade policies affecting less developed countries would, of course, involve the interests of a number of countries, but these recommendations would be specific and directly related to the export and development problems of the countries in question. This is important because too often in the past, industrialized countries have provided large sums of money for promoting economic growth in less developed countries while at the same time maintaining trade policies which were inconsistent with their foreign aid objectives. The job of the committee would be to tie trade and aid together in a single package and show how each depended upon the other for successful development in a series of specific cases.

5. The committee would, upon the request of low income countries, review the latter's long-range development plans from the standpoint of their implications for long-run balance of payments equilibrium and would make its recommendations available both to the country and to the various assistance agencies.

6. The committee would review proposals for international commodity agreements, both with respect to the feasibility of the agreements in achieving their objectives and of their relationship to the internal development programs of individual producer country members, and would make its findings available to prospective exporting and importing member countries and to the various external assistance agencies.

This coordinated approach to the problem of balance of payments difficulties arising from instability of export proceeds would not rule out the possibility of countries obtaining assistance beyond that which they might appropriately receive from the IMF, but this assistance would not be automatic and would provide, in effect, financing both for the maintenance of essential investments in accordance with the country's development plan and for the redirection of investment designed to achieve both greater stability of foreign exchange income and a rate of growth in foreign exchange earnings consistent with the country's long-term development goals. It might be objected that if funds for meeting export shortfalls were not provided more or less automatically in the form of free exchange and were tied to specific investment projects, they could not be provided soon enough to prevent an interruption in the flow of capital goods and other imports essential for continued growth. This would not necessarily be the case, however, if external assistance agencies were maintaining a close and continuous review of a country's development 
progress and programs. Thus, agencies like the Inter-American Development Bank or the Agency for International Development (AID) could provide financing sufficient to maintain a country's investment programs in the face of sharp reductions in export earnings. They would, however, want to make sure that what they were financing was not simply the maintenance of consumption or of investment for luxury apartments or public buildings not essential to basic economic growth. In addition, assistance agencies in providing special financing arising out of export shortfalls would want to see that the recipient countries give special emphasis to projects designed to improve their long-run balance of payments position. 